\title{
Tannin-Based Deflocculants in High Temperature High Pressure Wells: A Comprehensive Review
}

\author{
Michael Kwadwo Fokuo',2, Wilberforce Nkrumah Aggrey', Mizpah Ama Dziedzorm Rockson²*, \\ Yen Adams Sokama-Neuyam1, Patrick Boakye ${ }^{2}$, Gershon Amenuvor ${ }^{3}$, Kwame Sarkodie', \\ Emmanuel Pinto ${ }^{1,2}$, Hassan Karimaie ${ }^{1}$
}

\footnotetext{
${ }^{1}$ Department of Petroleum Engineering, Kwame Nkrumah University of Science and Technology, Kumasi, Ghana ${ }^{2}$ Department of Chemical Engineering, Kwame Nkrumah University of Science and Technology, Kumasi, Ghana ${ }^{3}$ Department of Chemistry, Kwame Nkrumah University of Science and Technology, Kumasi, Ghana Email: *madrockson.coe@knust.edu.gh
}

How to cite this paper: Fokuo, M.K., Aggrey, W.N., Rockson, M.A.D., Sokama-Neuyam, Y.A., Boakye, P., Amenuvor, G., Sarkodie, K., Pinto, E. and Karimaie, H. (2021) Tannin-Based Deflocculants in High Temperature High Pressure Wells: A Comprehensive Review. Advances in Chemical Engineering and Science, 11, 263-289.

https://doi.org/10.4236/aces.2021.114017

Received: September 3, 2021

Accepted: October 16, 2021

Published: October 19, 2021

Copyright $\odot 2021$ by author(s) and Scientific Research Publishing Inc. This work is licensed under the Creative Commons Attribution International License (CC BY 4.0).

http://creativecommons.org/licenses/by/4.0/ (c) (i) Open Access

\begin{abstract}
Clay deflocculants that are commonly used in water-based muds under high temperature high pressure (HTHP) oilwell drilling conditions have been found to contain chromium which is toxic. Tannin-based deflocculants are regarded as a more environmentally friendly and suitable alternative to the chrome-based deflocculants. However, tannin-based deflocculants have not been studied extensively and understood completely, and for the past two years, there have not been many active pieces of research in the area. To advance research in the area, there is a need to critically and holistically review research works that have been done so far on tannin-based deflocculants as drilling mud additives to identify research challenges and opportunities. This review paper provides an overview of tannin-based deflocculants used in water-based muds under HTHP drilling conditions, including the various forms, thermal stability, deflocculating ability and environmental acceptance of the deflocculant. The review revealed that under HTHP conditions, modified and unmodified tannin-based deflocculants both deflocculate water muds well and are thermostable. However, only a few studies have been conducted on their usage as deflocculants at temperatures of $150^{\circ} \mathrm{C}$ or above. The research gaps identified if pursued could advance the use of tannin-based deflocculants as green substitutes for the conventional chrome-based deflocculants.
\end{abstract}

\section{Keywords}

Deflocculant, Tannin, Drilling Fluid, Bentonite, Flocculation, High Temperature 


\section{Introduction}

Fossil sources continue to dominate the world energy mix in spite of tremendous efforts to produce energy from alternative sources [1]. Owing mainly to population growth, energy demand is growing rapidly worldwide. As such, drilling activity in deep oil and gas reservoirs is continually on the rise in order to supply this demand [2]. Deep drilling entails drilling to vast depths in order to reach the desired formations, which results in deep wells that are usually characterized by high temperatures and pressures [3]. These deep wells have thus been classified according to their bottom hole static temperature (BHST) and bottom hole static pressure (BHSP). High-temperature high-pressure (HTHP) wells, for example, have $\mathrm{BHST}$ and $\mathrm{BHSP}$ values ranging from $150^{\circ} \mathrm{C}$ to $205^{\circ} \mathrm{C}$ and 69 to $138 \mathrm{MPa}[4]$.

During drilling operations, a drilling fluid must be circulated in order to remove the cuttings produced by the drill bit, among other things. Drilling fluid, also known as drilling mud, includes a variety of chemicals in addition to the base fluid and each of these chemicals serves a distinct function. The chemicals or additions to the base fluid are generally called additives and the additives are grouped according to the functions of additives. For example, additives that control filtration properties are called filtrate reducers, those that increase the density of drilling fluids are also called weighting materials, while those that modify the fluid rheology are referred to as viscosifiers [5]. WBDFs are currently the most widely used drilling fluids. Several WBDF systems exist and they generally include bentonite clay, a cost-effective additive to provide the fluid with the desired rheological properties. Oil-based drilling fluids are the traditional drilling fluids used to drill high-temperature wells. Water-based drilling fluid systems have various advantages over oil-based drilling fluid systems from an economic and environmental standpoint. Water-based drilling fluid has gradually replaced oil-based drilling fluid in high-temperature well drilling [6]. At these temperatures, however, most typical water-based systems start to become unstable [7]. High temperatures in deep wells can cause clay particles in the drilling fluid to flocculate and mud additives to deteriorate, resulting in undesirable departures from the initially planned mud properties [8] [9]. As a consequence, the mud becomes unstable, resulting in poor drilling fluid performance. Usually, deflocculants are added to such drilling fluids to curb flocculation issues as well as disperse the muds. The dispersed WBDF system, for example, uses deflocculants (also known as thinners) extensively to prevent the formation of gel structures, thus reducing the propensity of the fluid to flocculate and thicken in HTHP applications [10] [11].

In HTHP drilling operations, chrome-based deflocculants such as chrome lignosulfonates (CLS) are widely used because they are excellent deflocculants and stable at these elevated temperatures. Chrome-based deflocculants have been shown to be toxic in addition to having chromium, a heavy metal [12] [13]. Chromium is found in the environment in two valence states (trivalent and 
hexavalent), and while it is an essential element in many organisms, including humans, and is useful in many industries, chromium toxicity has a negative impact on plant metabolic activities (resulting in hampered crop growth and yield and reduced quality of crop produce) as well as having toxicological, mutagenic and carcinogenic effects in humans and other aquatic and terrestrial organisms [14] [15]. Records have shown that reliable and environmentally friendly deflocculants are aimed at replacing existing ones that can cause environmental problems [16] [17] [18]. Due to easy accessibility, thermostability and environmental benign nature of tannins, a number of tannin-based deflocculants (TBD) have been developed through studies and have gained special attention as a more environmentally friendly and suitable alternative to chrome-based deflocculants. However, tannin-based deflocculants have yet to be studied extensively and understood completely, and research on this subject appears to be at a standstill. This paper provides an overview of tannin-based deflocculants used in water-based muds under HTHP drilling conditions, including the various forms, thermal stability, deflocculating ability and environmental safety of the deflocculant.

This paper is divided into nine sections: the first is the introduction; section 2 provides background information on plant tannins; section 3 describes flocculation and deflocculation phenomena as they apply to the drilling fluids industry; section 4 summarizes relevant previous literature on tannin-based deflocculants; sections 5, 6, and 7 discuss performance, high temperature tolerance, and environmental assessment and economic analysis of tannin-based deflocculants as additives in high temperature water-based muds respectively; section 8 presents some challenges facing the use of these deflocculants; and section 9 summarizes the review's findings, pointing out some knowledge gaps that need to be addressed more thoroughly.

\section{General Evaluation of Tannins}

Phenolic polymers (polyphenols), commonly known as tannins constitute one main group under phenolic phytochemicals [19]. However, tannins are actually a class of polyphenols. They are plant secondary metabolites mostly characterized by a molecular weight ranging from 500 to 20,000 Daltons. Also, they are able to bind and precipitate proteins, alkaloids and carbohydrates. This class of polyphenols is found in both vascular and non-vascular plants, including algae, and is among the most common plant biopolymers. Tannins consist of many functional groups but the dominant ones are the hydroxyl and carboxyl groups. They also have a variety of technologically important properties as well as various biological activities such as antioxidant, anti-carcinogenic, antiviral, anti-inflammatory, antipyretic, antihyperglycemic, and analgesic, making them useful in food, cosmetic, and pharmaceutical formulations [20]-[29].

For current technical applications, soluble tannins are usually extracted from the bark and heartwood of black wattle (acacia), quebracho, pine, sumac, oak, 
chestnut, tara, and eucalyptus trees. Besides that, residual wastes generated by the agricultural and food processing industries are another source to produce large amounts of tannin extracts; waste from these industries is known to be a rich and inexpensive source of tannin recovery. Significant amounts of waste biomass are produced each year around the world, with few uses. Other than composting [30] or being utilized as renewable energy resource, these wastes are sent to landfills which emit methane (a greenhouse gas that contributes to global warming) [20] [31] [32]. The efficient recovery of tannins from waste biomasses increases profitability while lowering environmental effects [30] [33].

Since tannins have a number of molecular structures, they are usually divided into condensed tannins (polymers of catechin and epicatechin) and hydrolysable tannins (polymers of gallic acid or ellagic acid) [19] [34].

Hydrolysable tannins can easily be hydrolysed by acids or enzymes into phenolic carboxylic acids and sugar or related polyhydric alcohols. Depending on the nature of the phenolic carboxylic acids, hydrolysable tannins are classified into gallotannins and ellagitannins. Gallotannins are hydrolysed to produce gallic acid, while ellagitannins are hydrolysed to produce hexahydroxydiphenic acid, which is usually isolated as its stable dilactone, ellagic acid (see Figure 1) [22] [23]. Tannin extracts from Castanea sativa (chestnut) bark and Quercus valonea (valonea) acorn cups are classified as ellagitannins, while those from Caesalpinia spinosa (tara) fruit pods are classified as gallotannins.

The structures of condensed tannins are far more complex than those of hydrolysable tannins. Condensed tannins, also known as proanthocyanidins, are oligomers or polymers of the flavan-3-ol basic structure with C4-C6 or C4-C8 interflavonoid linkage, which may contain gallic acid esters [20] [22] [35] [36]. Condensed tannin monomers can have up to six hydroxyl groups, many of which are located on aromatic A and B rings (see Figure 2). Procyanidin and prodelphinidin are two forms of condensed tannins based on the distribution of $\mathrm{OH}$ groups on the aromatic ring $\mathrm{B}$; prodelphinidin has three $\mathrm{OH}$ groups on ring B whereas procyanidin has only two [26]. Condensed tannins (non-hydrolysable tannins) polymerize in the presence of acids, resulting in amorphous phlobaphenes or tannin reds [23]. Condensed tannins can be found in Acacia mearnsii (black wattle) bark, Schinopsis balansae and Schinopsis lorentzii (quebracho) barks, pine barks, and eucalyptus species bark. Tannin extracts from plants such as Rhus tripartitum (sumac) root bark and Phyllanthus niruri have roughly equal amounts of both hydrolysable and condensed tannins [37] [38].

Tannins were used in some industries for a long time until synthetic chemicals were developed to replace them. However, the majority of these synthetic substances have now been discovered to be harmful to human and animal health as well as the environment. Because tannins have a low environmental impact, they have seen a renaissance in those industries, as well as in others where tannins have found new uses [39]. For example, tannins have been extensively studied as natural binders with mechanical properties comparable to synthetic resins 


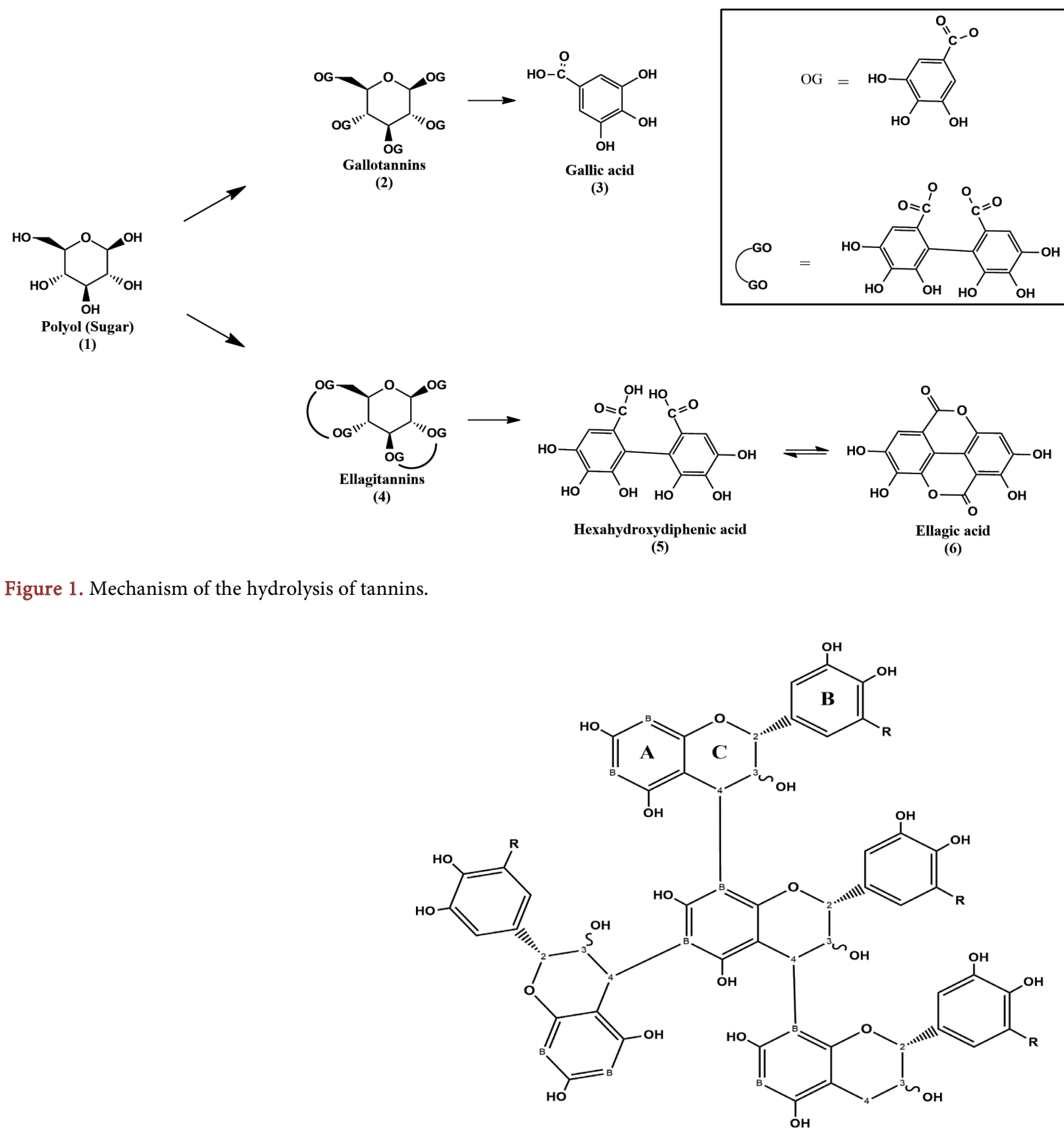

Figure 2. Structure of a condensed tannin oligomer.

because urea or phenol formaldehyde adhesives, as well as other commonly used synthetic resins, are known to emit formaldehyde (a chemical harmful to human health) from wood boards when used as a bonding agent [40]. Condensed tannins, in particular, are now widely recognized for their ability to be employed as adhesive materials.

Plants produce tannins to protect themselves from herbivore attacks and microbial activity [22] [41]. Furthermore, these phytochemicals have been discovered to provide plants with thermal defence [42] [43]. Tannins have also shown excellent thermal stability in a variety of applications. Tannin-based rigid foams, 
for example, have been shown to have thermal insulating properties comparable to synthetic foams like polyurethanes. They also have the advantage of not being combustible and showing burning intumescence [36]. Soluble tannins or tannin extracts have been the subject of many thermogravimetric studies. Table 1 summarizes the findings of these studies. Natural tannins can generally be used at temperatures below $240^{\circ} \mathrm{C}$, according to the thermogravimetric data of tannin extracts.

The peak degradation temperature $\left(\mathrm{T}_{\text {peak }}\right)$ refers to the temperature at which the maximum rate of weight loss of tannin samples occurs. The temperature at which $10 \%$ and $50 \%$ weight loss of tannin sample occurs is represented by $\mathrm{T}_{10 \%}$ and $\mathrm{T}_{50 \%}$ respectively. From Table 1, the thermal parameters $\mathrm{T}_{\text {peak }}, \mathrm{T}_{10 \%}$ and $\mathrm{T}_{50 \%}$ ranges from $240^{\circ} \mathrm{C}$ to $486^{\circ} \mathrm{C}, 110^{\circ} \mathrm{C}$ to $300^{\circ} \mathrm{C}$, and $290^{\circ} \mathrm{C}$ to $750^{\circ} \mathrm{C}$ respectively. Thermal parameters and thermal decomposition profile of tannins may differ with various tannin extracts. The changing thermal behaviour of different tannin extracts can be explained in part by differences in operating parameters like heating rate and heating atmosphere [22] [36] [37] and more importantly, in part by tannin source, tannin types present, purity, extraction process and inherent chemistry of tannin samples [23] [24] [44] [45] [46].

\section{Flocculation and Deflocculation}

Ostensibly, most WBDFs are bentonite dispersions because WBDFs need more than just water to achieve the desired rheology. Drilling fluid viscosity must be within certain limits, as it must be adequate to remove the cuttings while not being too high to necessitate excessive pumping power and inflict unnecessary wear and tear on the pumps. As a result, WBDFs usually include bentonite, a low-cost additive whose main constituent is montmorillonite clay mineral, to give the drilling fluid the desired rheology. Bentonite is used to build a thin, low permeability filter cake on the wellbore wall to reduce filtration loss and prevent formation damage, in addition to providing sufficient viscosity for transporting cuttings out of the well.

The montmorillonite particles exist in packets and the small size and high surface area of the clay packets, along with their high ability to hydrate, swell, and disperse in water, are thought to be the cause of these unusual properties previously mentioned. The individual montmorillonite particle has a plate-like structure with an octahedral sheet in the middle and two tetrahedral sheets on either side [47] [48] [49]. Also, the individual particles have two distinct surfaces: negatively charged face surfaces and depending on the mud $\mathrm{pH}$, either positively or negatively charged edge surfaces. Usually, at the regular mud $\mathrm{pH}$ range of 9 to 11, the edge surfaces are positively charged. In the dry state, the clay packets exist in face-to-face stacks like a deck of playing cards, but the clay platelets begin to change when exposed to water. Depending on the clay-water interactions that may occur when bentonite is exposed to water, the clay packets will either maintain the original face-to-face stacks or change to face-to-edge, 
edge-to-edge or a combination of the associations [50] [51].

Water-based muds, like most drilling muds, are non-Newtonian and shear thin, which means that the viscosity decreases as the shear rate increases. The interaction of solids in the mud causes this non-Newtonian behaviour. Solid-solid interaction causes flow resistance due to either electrical forces of attraction and repulsion of the charged surfaces of the solids or purely mechanical resistance to flow of the particles and fluid. The electrical interaction of solids is primarily responsible for low-shear-rate viscosities, while mechanical interactions are primarily responsible for high-shear-rate viscosities [50].

In a clay-water environment like bentonite mud, five different interactions can occur: hydration, dispersion, flocculation, deflocculation and aggregation. Hydration is always the first stage of bentonite-water interaction. As dry bentonite is mixed with water, it adsorbs water and expands. When exposed to water, Na-bentonite, for example, can expand more than ten times its dry volume.

Dispersion follows hydration and is described as follows: when more water is adsorbed, the water pushes the platelets further apart, reducing the attractive forces, which are gradually lost when the platelets split apart into smaller ones and scatter within the water medium due to mechanical agitation (and in some other instances, heat or chemical means). In other words, hydration causes swelling where the distance between the layers has increased so much that the attractive forces between the layers are reduced and agitation at a high shear rate induces the layers to separate thus the clay platelets become smaller in size and disperse in the mud. When more platelets are dispersed, the viscosity of the mud increases. Flocculation occurs in dispersed clay suspensions when the mechanical agitation is stopped or is at low shear rates. The dispersed clay platelets spontaneously form flocs due to the attraction between negative face and positive edge charges. This interaction results in suspension gelation and an increase in viscosity. As a chemical deflocculant is added to flocculated mud, the positive edge charges are covered, and attraction forces are greatly reduced. The use of a deflocculant, also known as a thinning agent or thinner reduces the viscosity and gelation of the suspension [50].

Also, aggregation occurs as a result of ionic or thermal conditions, changes the hydrational layer surrounding clay platelets and allows platelets to form a dehydrated, face-to-face configuration in a water-based mud. Plastic viscosity, yield point, and gel strength all reduce drastically as a result of aggregate formation. Both flocculation and aggregation may exist at the same time, or one interaction may predominate [47] [51]. Through chemical means, such as the addition of dispersing agents or dispersants, the aggregated mud can be dispersed again. Deflocculants and dispersants are sometimes used interchangeably, owing to the fact that both additives cause associated particles to break apart and disperse in the mud, or that most deflocculants may also function as dispersants.

According to [50], the fundamental clay reactions of dispersion, deflocculation, aggregation, and flocculation can be triggered in a variety of ways as tem- 
perature rises. Increased temperature, on the other hand, induces only two main clay reactions in simple clay suspensions: flocculation and dispersion of the clay plates. If there are a lot of electrolytes in the water, flocculation is normally followed by aggregation [52].

Flocculation is undesired during mud circulation as it alters the rheological properties of the fluid and causes high fluid losses into the formation. Rheological and filtration properties such as yield point, gel strength, apparent viscosity, filtrate volume and filter cake thickness are all affected [53]. It is still ambiguous regarding the effect of flocculation and gelation on plastic viscosity and no consensus exist whether deflocculants affect this rheological parameter. Gel-like drilling muds can cause stuck pipes, potentially causing surges, and have a higher viscosity, necessitating more pumping energy [54].

Since any change in the low shear rate of viscosity is expressed in the yield point value, it is a good indicator of the propensity of clay particles to join together and form a flocculated structure. Furthermore, the gel strength estimates the shear stress required to initiate the flow of a fluid that has been stationary for some time, implying that something that encourages or inhibits the bonding of clay layers will increase or decrease the dispersion's tendency to gel [11] [55]. Owing to the neutralization of the positive edges of the clay particles in the presence of deflocculants, the clay particles cannot be bound together. The yield point and gel strength both decrease as a result of this. It is therefore well understood that deflocculants reduce the yield point and gel strength of drilling fluids [11].

Deflocculants with good tolerance to high salinity or contaminants are very attractive because saltwater flows and salt formations, including salt domes, salt stringers, etc., can alter the properties of the drilling fluid. As previously stated, they can cause aggregation. Furthermore, calcium ions from gypsum/cement can solubilize in drilling fluids and flocculate bentonite clays in the WBDF system, so gypsum/cement and other salts are generally referred to as contaminants in the WBDF system [56]. It is therefore desirable to have deflocculants that have good tolerance to high salinity or contaminants and continues to deflocculate flocculated muds.

\section{Tannin-Based Deflocculants}

Since the early years of the twentieth century, tannin-based deflocculants (TBD) have been used in the drilling fluid industry for drilling under ambient conditions until recently, when they are replacing commonly used chrome-based deflocculants such as Cr-lignosulfonate (CLS) and Fe-Cr-lignosulfonate (FCLS) for high-temperature applications [18] [57]. TBDs are divided into two categories in this study: modified and unmodified forms.

\subsection{Modified Tannin-Based Deflocculants}

Reference [56] suggested that a deflocculant for drilling under high-temperature 
conditions must be thermally stable and effective as a deflocculant at the temperatures encountered in wells, as well as economically and environmentally acceptable. Chromium and other metals like iron acted as thermal stabilizers in chrome-based deflocculants. Similarly, in modified TBDs, tannin with or without other metal ions such as iron, tin, etc. are added to existing deflocculants like lignosulfonate/lignite to act as thermal stabilizers.

Chrome-based deflocculants such as CLS contain chromium because, in addition to causing flocculation, high temperatures may decompose thermolabile additives such as lignosulfonate, and this affects the proper functioning of the additive and the performance of the drilling fluids as a whole. This addition of chromate salts was necessary in order to improve the thermal stability of lignosulfonate. Instead of chromium, naturally occurring tannins are now used to provide thermal stability that deflocculants such as lignosulfonate and lignite require to be effective for high-temperature applications. Also, some researchers believe that tannins promote the cross-linking process of lignosulfonate with tannins [58].

Reference [59] used tannins derived from the bark of Rhizophora spp. to make tannin-lignosulfonate (TLS), which they then tested as a deflocculant. Drilling fluids formulated with Rhizophora tannin-lignosulfonate (RTLS) had their rheological properties, such as plastic viscosity, yield point, and gel strength, measured at room temperature and compared to a chrome-based deflocculant. With higher RTLS deflocculant concentrations, the drilling fluid's yield point and gel strength were effectively decreased without a significant change in plastic viscosity. Furthermore, the RTLS is classified as thermally stable because research shows that, although it begins to degrade at $200^{\circ} \mathrm{C}$, it reaches a peak degradation temperature of around $280^{\circ} \mathrm{C}$, which is much higher than the bottom hole temperature of HTHP wells.

Reference [10] extracted tannins from Acacia spp. and used the extracts to make Fe-tannin-lignosulfonate (FTLS), which is basically a TLS made by crosslinking lignosulfonate with tannin extract in the presence of formaldehyde and then chelating with ferrous ions. Only one rheological property, gel strength, was measured, and it was done at room temperature. The gel strength of the drilling fluid was decreased by the FTLS deflocculant, which was close to that of some industrial grade deflocculants used in the analysis. The FTLS made from lignosulfonate and Acacia spp. tannin are thermostable, according to thermogravimetric analysis, with a peak degradation temperature of about $294^{\circ} \mathrm{C}$. The thermal stability of the FTLS formed was found to be influenced by the ratio of tannins to lignosulfonate used in the crosslinking process of lignosulfonate with naturally occurring tannins.

Reference [18] also made Fe-tannin-lignosulfonate, a chrome-free lignosulfonate that is thermally stable at HTHP well conditions. The drilling mud test analysis indicates that, when compared to the commonly used FCLS deflocculant, FTLS has better thinning properties, resistance to a higher temperature 
(that is, $150^{\circ} \mathrm{C}$ ), and comparable tolerance to high salinity. The adsorption isotherms of lignosulfonate, TLS, and FTLS on bentonite clay showed that both crosslinking and chelation of lignosulfonate greatly enhance its adsorption onto the clay [18]. Furthermore, FTLS adsorbed on both the positively and negatively charged surfaces of bentonite platelets, while lignosulfonate and TLS only adsorbed on the positively charged edges. The adsorption of FTLS to the faces of the bentonite particles is attributed to the bridging of chelated divalent cations $\left(\mathrm{Fe}^{2+}\right)$ between the polymer and the surface.

Reference [58] synthesized tin-tannin-lignosulfonate (TTLS), which was similar to the FTLS synthesized as in [18] but differed in the chelating ions used. According to Reference [58], chelating with stannous ions was justified by the fact that it was less toxic than chromium. The results of the performance assessment test of TTLS as a deflocculant at temperatures up to $90^{\circ} \mathrm{C}$ showed that TTLS had a good temperature tolerance and performed remarkably compared to lignosulfonate. The TTLS, similar to the FTLS, showed good tolerance to high salinity.

Reference [60] produced a new deflocculant product called Fe-tannin-lignin (FTL) by reacting soda lignin with tannin and ferrous ion. Using 20 percent (v/v) sulfuric acid, soda lignin was extracted from the black liquor of oil palm empty fruit bunch fibres. The researchers wanted to see if lignin purification was needed to improve FTL efficiency. Drilling fluids formulated with the pure FTL (FTL purified) were compared with those formulated with the impure FTL (FTL impurified) and a commercial thinner, lignosulfonate, for filtration and rheological properties such as yield point, apparent and plastic viscosities. In general, the FTL purified and the FTL impurified produced similar results, implying that the purification step is unnecessary. This FTL deflocculant has also been shown to be resistant to salt contamination and high temperatures $\left(160^{\circ} \mathrm{C}\right)$.

\subsection{Unmodified Tannin-Based Deflocculants}

The unmodified TBDs make up the second category of TBDs. They are essentially soluble tannins (crude tannin extracts). From the early decades of the twentieth century, they have mainly been used as deflocculants for drilling under atmospheric conditions even before modified TBDs were introduced in the drilling fluid industry. Several feasibility studies on the use of naturally occurring tannins as high-temperature deflocculants without any modifications have recently been published [47] [61] [62] [63]. These studies were probably influenced by the discovery that tannins can withstand high temperatures as depicted by the use of modified forms, together with the knowledge that they are good deflocculants.

Reference [63] investigated the effects of tannins extracted from Caesalpinia coriaria (dividivi) fruit pods on the rheological properties of WBDF contaminated with gypsum and at high temperatures up to $177^{\circ} \mathrm{C}$. Before ageing, unmodified dividivi tannins (UDT) in a water-based drilling fluid with gypsum 
showed deflocculating properties similar to commercial tannins (modified quebracho). The deflocculating performance of the dividivi tannins formulated mud was nine times higher than that of commercial tannins after ageing. According to [63], the high deflocculating efficiency of dividivi tannins at $177^{\circ} \mathrm{C}$ without chemical modifications indicates that dividivi tannin extracts have chemical characteristics that do not require modification for use as deflocculating agents at such a high temperature.

Reference [62] reported the deflocculating efficiency of UDT as an additive for WBDF in subsequent analysis. The results were close to those in [63], who found that the dividivi tannins formulated mud had a deflocculating efficiency that was nine times higher than commercial tannins. Bioassays performed on UDT-formulated drilling fluids using bioindicators, freshwater microalgae (Scenedesmus dimorphus) and freshwater fish (Poecilia reticulata) showed no effect on population growth. As a result, UDT is regarded as non-toxic and environmentally friendly. Field test results from four oilwells showed that the rheological behaviour of UDT-formulated drilling fluids was satisfactory. Even so, these wells are not indicated as high temperature, high pressure wells [62].

The effect of black myrobalan tannin extract on the rheological behaviour of a heavy weight mud contaminated with salt was investigated as in [64]. They studied the effect of ageing and hot rolling at $93^{\circ} \mathrm{C}$ and discovered that hot rolling decreases the rheological properties of drilling mud while ageing statically increases them. Both before and after hot rolling, black myrobalan tannin extract was found to minimize mud rheological properties and increase filtration volume without affecting mud weight. Yield point decreased more than other rheological parameters studied, such as gel strength and viscosity. While deflocculants are designed to reduce the gel strength and yield point of thickened drilling muds, increasing the filtration volume is undesirable. The explanation for this is that a high filtration volume implies a higher incidence of drilling fluid seepage through the bentonite filter cake.

Reference [47] evaluated the efficacy of Oak Seed Extract (OSE) as a chrome-free, bio-based deflocculant in water-based drilling mud, taking into account the impact of temperature (ranging from $28^{\circ} \mathrm{C}$ to $149^{\circ} \mathrm{C}$ ) and contaminants (for example, sodium chloride, calcium chloride, and cement). The OSE kept the aqueous suspension stable by limiting the tendency of water-based drilling fluid to flocculate and thicken. While not being able to reduce plastic viscosity, OSE reduces rheological and filtration parameters such as yield point, gel strength, and fluid loss. In cement-contaminated mud, the deflocculating efficiency of OSE was more profound due to its acidic nature. As a result, it was suggested that when dealing with ultra-high $\mathrm{pH}$ conditions caused by cement, pre-treating the drilling mud with OSE is necessary.

Reference [61] used Rhizophora mucronata spp. tannin extract (RMTE) as a deflocculant in water-based muds. The effectiveness of RMTE as a deflocculant 
was compared to that of Modified Desco Tannin (MDT), a commercial deflocculant. Rheological and filtration properties tests were carried out on RMTE and MDT formulated drilling muds before and after hot rolling tests at different temperatures of $107^{\circ} \mathrm{C}, 121^{\circ} \mathrm{C}, 135^{\circ} \mathrm{C}$ and $149^{\circ} \mathrm{C}$. The experimental data indicate that the RMTE has similar drilling fluid properties to the commercial MDT, but its use as a drilling fluid should be limited to $8 \mathrm{~g}$ per laboratory barrel, which is equal to $350 \mathrm{ml} \mathrm{WBDF}$, and under the same working conditions, where it outperforms the commercial deflocculant. The newly developed RMTE deflocculant was found to be temperature resistant and stable with high temperatures. Furthermore, Reference [61] studied the extraction of RMTE using various solvents and concluded that water is the safest solvent to use since it is safer and less costly than methanol and yields the most RMTE.

Reference [65] studied the rheological and filtration properties of WBDF when Rhizophora mucronata tannin was used as a deflocculant. At a maximum post-ageing temperature of $177^{\circ} \mathrm{C}$, the formulated mud-rheological properties such as plastic viscosity, yield point, $10 \mathrm{sec}$ gel strength and 10 min gel strength tend to decrease significantly by 28.2 percent, 33.3 percent, 33.3 percent and 27.3 percent, respectively. As far as filtration performance is concerned, the HTHP filtration volume and the mud cake thickness decreased significantly by 69.2 percent and 27.3 percent respectively at the highest post-ageing temperature of $177^{\circ} \mathrm{C}$. The rheological and filtration properties were affected by tannin concentrations and the optimal tannin dosage was $6 \mathrm{~g}$ per single laboratory barrel. The rheological and filtration properties of tannin were compared with commercial deflocculants, with differences between 5 and 14 percent. WBDFs formulated with Rhizophora mucronata tannin have been found to be able to withstand high temperatures of approximately $177^{\circ} \mathrm{C}$, which is suitable for HTHP drilling operations.

\section{Performance of Tannin-Based Deflocculants under High-Temperature Conditions}

Deflocculating or thinning ability of additives is mainly determined by the measurement of rheological and filtration properties because flocculation adversely alters the rheological and filtration properties of drilling fluids, as it has already been advanced. Rheological data are most frequently fitted to the Bingham plastic model and, in addition to gel strength; rheological parameters such as yield point, plastic and apparent viscosity are calculated. Regarding filtration properties, the parameters usually defined are the filtrate volume and filter cake thickness. Moreover, the potency of new additives supposedly functioning as high-temperature deflocculants capable of restoring the drilling fluid properties after flocculation of the fluid can be supported with particle size and zeta potential measurements [18] [47].

TBDs used as high-temperature deflocculants have generally been successful in significantly lowering both the rheological and filtration parameters that in- 
crease as a result of flocculation [63] [65]. Furthermore, TBDs have shown comparable or increased thinning efficiency at high temperatures when compared with commercial deflocculants, which also means that they are thermally stable at those temperatures [18] [60]. There are, however, some exceptions; for example, when used as a high-temperature deflocculant, the black myrobalan tannin extract reduced all measured parameters except one: with the addition of the deflocculant, the filtrate volume increased [64].

While some TBDs tend to increase or decrease plastic viscosity, other TBDs have no significant effect on this parameter. In the case of RTLS, when small amounts of RTLS are added, plastic viscosity increased and decreased with the further addition of RTLS [59]. Besides, it is clearly shown that the quantity of TBDs applied to drilling fluids has an impact on their ability to deflocculate. Many TBDs are effective when small quantities of TBD are used and some efficiency increases with increasing amounts of TBD, but when they exceed a threshold, they become inefficient [61] [65]. The term optimal dosage or quantity typically refers to that specific quantity or concentration of TBD that gives the best deflocculating efficacy just before the threshold quantity that results in inefficiency is reached.

In terms of efficiency, TBDs are found to be more compatible within the working $\mathrm{pH}$ range (that is, 9 to 11) of bentonite containing WBDFs. The efficiency of most TBDs as deflocculants is compromised when the mud $\mathrm{pH}$ is beyond this range [18] [58]. With or without the addition of TBDs, the mud density, another drilling fluid property, remains reasonably constant [64]. In other words, the TBDs do not change the mud density. In the meantime, different TBDs have worked well in various WBDF freshwater systems with different mud densities.

Supporting an argument with adequate evidence is crucial, and in the case of deflocculants, particle size and zeta potential measurements will accomplish this. An increase in the size of bentonite particles can be considered the first physical alteration of bentonite mud flocculation. The estimation of the particle size of bentonite particles in the presence of aqueous TBDs solution could provide a clear sign of bentonite flocculation or deflocculation [47]. Bentonite, which is a smectite-type clay mineral, may also exhibit complex electrokinetic and rheological properties when dispersed in aqueous media, in particular with electrolyte species [66]. For the characterization of particle suspensions, Zeta potential measurements are valuable. If all the suspended particles have a strong negative or positive zeta potential, they appear to repel each other and the particles would have no tendency to come together. However, if the particles have low zeta potential values, there will be insufficient repulsion to prevent the particles from coming together and flocculating. In general, the dividing line between stable and unstable suspensions is known to be +30 or $-30 \mathrm{mV}$, with particles having zeta potentials beyond these limits considered stable [67].

As far as electrolytes are concerned, the majority of contaminants considered 
in the drilling fluid industry are electrolytes and the presence of contaminants tends to further destabilize the WBDF system as a result of aggregation. Moreover, most of the early deflocculants used in the industry not only had low tolerance of temperature but also electrolyte tolerance [68]. TBDs, however, have demonstrated high electrolyte tolerance and continue to work well in the presence of these contaminants [18] [47]. Also, TBDs tested by far have no inhibition properties, unlike potassium chloride and polyamine, which are used as clay stabilizers [11] [47]. The common outcomes of these studies on the efficacy of TBDs as high-temperature deflocculants were positive, confirming TBDs as efficient deflocculants under high-temperature drilling operations.

\section{High Temperature-Tolerance of Tannin-Based Deflocculants}

A further requirement of deflocculants used under high-temperature conditions is that they must be thermally stable at temperatures encountered in drilling oil wells (in this context HTHP conditions) in addition to their capacity as deflocculants in this temperature range. As explained above, high temperatures can lead to flocculation and degradation of additives, including deflocculants with poor temperature stability. Natural tannins are phytochemicals that are thermostable and may be inferred from Table 1. Moreover, both modified and unmodified TBDs are shown to be tolerant of high temperatures encountered under HTHP conditions [10] [63].

Testing of thermal stability of tannins (mostly plant extracts) in the laboratory is usually performed using thermogravimetric analysis (TGA). However, the TGA approach is scarcely used in the assessment of TBD temperature tolerance [59]. The most prevalent approach is to measure and compare the rheological and filtration properties at different temperatures (done by ageing thermally) of drilling fluids formulated with TBD and the control drilling fluid that is, without TBD or formulated with commercial deflocculant (whose temperature-tolerance range is known). So, the rheological and filtration properties of drilling fluids formulated with TBD with and without thermal ageing treatment are measured. Second, the performance of TBD as a deflocculant, with and without thermal ageing treatment, is contrasted with each other by using a commercial deflocculant as a control agent [61]. According to [64], thermal ageing using hot rolling treatments reduces rheological parameters and thermal ageing statically raises the same parameters.

\section{Environmental Acceptability and Cost Assessment of Tannin-Based Deflocculants}

The study of TBDs as high-temperature deflocculants resulted from a search for chromium-free or eco-friendly deflocculants. TBDs were deemed safe and environmentally friendly due to the fact that tannins used in both groups of TBDs are plant extracts (or natural). Not long ago, an ecotoxicological assessment of 
WBDF formulated with an unmodified TBD showed that WBDF is non-toxic, supporting the notion that natural tannins are environmentally safe and therefore eligible for TBDs to meet another criterion for high-temperature deflocculants [62].

Additionally, high-temperature deflocculants must be cost-effective. In the first place, with regard to TBDs of both classes, they are more economical and sustainable products due to the low cost and easy accessibility of the raw materials (plants and waste from the agricultural and food processing industries) from which extracts are produced, as well as, the simple and inexpensive production methods [32] [47]. Secondly, field test results show that TBDs can yield additional economic savings as unlike commercial deflocculants, as smaller quantities of TBDs are needed for drilling operations [62]. Finally, it can be asserted that the cost of discharging waste drilling fluids can reduce with the use of TBDs and also eliminate the additional costs that could occur as a result of drilling problems caused by the use of an eco-friendly but less productive HTHP well deflocculant. Therefore, when TBDs are used as the deflocculant in a specific drilling operation, the total drilling cost of developing the HTHP well can be considerably reduced.

\section{Challenges}

Moving tannin-based deflocculants from the lab to the field is a hurdle for the industry. Inadequate laboratory tests are a significant issue since most laboratory experiments contradict the fact that new additives or products should be tested in conditions as close to real-world conditions as possible. Currently, deflocculants are used in a variety of conditions, and tannin-based deflocculants, for example, can also serve as corrosion inhibitors or bactericides, or shale control inhibitors. Most laboratory studies, on the other hand, do not inform industry on how tannin-based deflocculants perform under these various conditions or on their secondary functions. Additionally, any interactions between the tannin-based deflocculant and other common additives used in real-world conditions must be considered at all times, which is typically neglected in many laboratory studies. Furthermore, in any performance evaluation, the cost of the mud additive in question is crucial. Laboratory research on tannin-based deflocculants, on the other hand, is not designed to compare the costs of the new product under study, that is, the tannin-based deflocculant, with the costs of conventional deflocculants. The laboratory tests performed to evaluate the performance of tannin-based deflocculants appear to be insufficient to justify a field trial.

Aside from the issue of insufficient laboratory tests, another key issue is accessibility. Regardless of the fact that tannins can be found almost everywhere in the world (in almost every plant), tannin-based deflocculants may be difficult to obtain since tannin content varies between plant species and plant sections such as bark and leaves. The effect of this difference in tannin composition with different plant species or plant sections on the efficacy of tannin-based defloccu- 
lants is unknown to researchers. If the results of this research show that variations in tannin content have no effect on deflocculant efficacy, then accessibility will not be an issue. If some impacts do emerge, however, accessibility may or may not be an issue, depending on the magnitude of the impact. Tannin-based deflocculants have only been developed from a few plants. If new tannin sources do not prove to be at least as successful as those already in use, these tannin-based deflocculants might not be sustainable in the long run.

\section{Summary and Conclusions}

WBDF systems are apparently bentonite dispersions. The use of WBDF systems in deep wells and reservoirs, especially dispersed systems, has increased enormously because there are environmental limitations on the widely used OBDFs. To avoid such systems from undergoing flocculation at high temperatures, WBDF systems are often pre-treated with deflocculants. However, the distinctly used chrome-based deflocculants are no longer permissible in certain regions around the globe because they comprise chromium.

The composition, efficiency and environmental safety of tannin-based deflocculants suitable for HTHP well applications were discussed. Different types of TBDs have been developed and can be primarily divided into two types, namely modified forms and unmodified forms. Pre-treatment of drilling fluids with TBDs typically stabilizes rheological parameters such as the yield point and gel strength of drilling fluids or minimize rheological parameters when added to the flocculated mud. Similarly, these bio-based deflocculants usually minimize filtration parameters such as filtrate volume and filter cake thickness. They are stable at higher temperatures and tolerant to contaminants such as salts, etc. They also work well in the presence of these contaminants, although the contaminants themselves may cause flocculation. Bioassay information on tannin extracts supports the view that naturally occurring tannins are environmentally safe. In summary, TBDs are considered to be environmentally friendly and equally effective, if not better than chrome-based deflocculants for HTHP well applications.

While thermogravimetric analysis is recommended for future studies to assess the thermal stability of TBDs that have the potential to be used under HTHP well conditions, the assessment of water-based muds formulated with these TBDs should also be done at high temperatures. However, no research has been conducted to investigate the effectiveness of TBDs above $177^{\circ} \mathrm{C}$. Moreover, there is no consensus about whether plastic viscosity, is a reasonable parameter to use when evaluating the performance of deflocculants. Also, little is known about the relationship between thermal ageing (hot rolling and static) treatments and flocculation and deflocculation phenomena. Moreover, the effect of different plant species from which the tannins are sourced, as well as different extraction processes, on the deflocculating performance of TBDs is still unknown. Tannins are known to have different structures and thus variations in tannin composi- 
tions of tannin extracts from different origins (i.e., plant species) and tannin production methods (dry and wet extraction). These studies will reveal whether certain plant species are indeed superior to others in terms of deflocculating capacity, requiring no chemical modifications or requiring some extraction processes to be optimized and some followed by additional processes to improve the deflocculating ability of TBDs.

Furthermore, the potential for producing TBDs from waste or residue from agri-food processing, as well as from chemically synthesized tannins has not been explored. More research is also required to back up the argument that TBDs, especially modified TBDs, are environmentally safe and non-toxic to a variety of bio-indicators found in the marine environment where waste drilling fluid is discharged. Finally, TBDs may serve as multifunctional additives such as temperature stabilizers, dispersants, corrosion inhibitors, bactericides or lubricity enhancers, which can be beneficial both technically and economically if investigated.

\section{Funding}

This review received funding from the GNPC Petroleum Chair Scholarship under the GNPC-KNUST MOU. Funding number is PE-001-201901-0102.

\section{Acknowledgements}

The authors would like to thank the Department of Petroleum Engineering, KNUST, specifically the Smart Fluids and Flow Assurance (SFFA) Research Group for fellowships and technical assistance. The authors are grateful for the financial support from the GNPC Petroleum Chair Scholarship under the GNPC-KNUST MOU.

\section{Conflicts of Interest}

The authors declare no conflicts of interest regarding the publication of this paper.

\section{References}

[1] Oseh, J.O., Mohd Norddin, M.M.A., Ismail, I., Gbadamosi, A.O., Agi, A. and Mohammed, H.N. (2019) A Novel Approach to Enhance Rheological and Filtration Properties of Water-Based Mud Using Polypropylene-Silica Nanocomposite. Journal of Petroleum Science and Engineering, 181, Article ID: 106264. https://doi.org/10.1016/j.petrol.2019.106264

[2] Liu, J., Dai, Z., Xu, K., Yang, Y., Lv, K., Huang, X. and Sun, J. (2020) Water-Based Drilling Fluid Containing Bentonite/Poly (Sodium 4-Styrenesulfonate) Composite for Ultrahigh-Temperature Ultradeep Drilling and Its Field Performance. SPE Journal, 25, 1193-1203. https://doi.org/10.2118/199362-PA

[3] Akpan, E.U., Enyi, G.C., Nasr, G., Yahaya, A.A., Ahmadu, A.A. and Saidu, B. (2019) Water-Based Drilling Fluids for High-Temperature Applications and Water-Sensitive and Dispersible Shale Formations. Journal of Petroleum Science and Engineering, 175, 1028-1038. https://doi.org/10.1016/j.petrol.2019.01.002 
[4] Amani, M., Al-Jubouri, M. and Shadravan, A. (2012) Comparative Study of Using Oil-Based Mud versus Water-Based Mud in HPHT Fields. Advances in Petroleum Exploration and Development, 4, 18-27.

[5] Lahalih, S.M. and Dairanieh, I.S. (1989) Development of Novel Polymeric Drilling Mud Dispersants. European Polymer Journal, 25, 187-192.

https://doi.org/10.1016/0014-3057(89)90073-6

[6] Abduo, M.I., Dahab, A.S., Abuseda, H., AbdulAziz, A.M. and Elhossieny, M.S. (2016) Comparative Study of Using Water-Based Mud Containing Multiwall Carbon Nanotubes Versus Oil-Based Mud in HPHT Fields. Egyptian Journal of Petroleum, 25, 459-464. https://doi.org/10.1016/j.ejpe.2015.10.008

[7] Kelessidis, V.C. (2009) Drilling Fluid Challenges for Oil-Well Deep Drilling. Proceedings of the International Multidisciplinary Scientific Geoconference \& EXPO, Modern Management of Mine Producing, Geology and Environmental Protection SGEM, Albena, 14-19 June 2009, 1-9.

https://www.researchgate.net/profile/V-Kelessidis-2/publication/237611661_DRILL ING_FLUID_CHALLENGES_FOR_OIL-WELL_DEEP_DRILLING/links/580869ee 08ae07cbaa54433c/DRILLING-FLUID-CHALLENGES-FOR-OIL-WELL-DEEP-DR ILLING.pdf

[8] Kelessidis, V.C., Christidis, G., Makri, P., Hadjistamou, V., Tsamantaki, C., Mihalakis, A., Papanicolaou, C. and Foscolos, A. (2007) Gelation of Water-Bentonite Suspensions at High Temperatures and Rheological Control with Lignite Addition. Applied Clay Science, 36, 221-231. https://doi.org/10.1016/j.clay.2006.09.010

[9] Sudharsan, J. (2018) Behaviour of Drilling Fluids on HPHT Well Conditions. International Journal of Advanced Scientific Research and Management, 3, 280-282. http://ijasrm.com/wp-content/uploads/2018/07/IJASRM_V3S7_689_280_282.pdf

[10] Ghazali, N.A., Naganawa, S. and Masuda, Y. (2018) Feasibility Study of Tannin-Lignosulfonate Drilling Fluid System for Drilling Geothermal Prospect. Proceedings of the 43rd Workshop on Geothermal Reservoir Engineering, Stanford, 12-14 February 2018, 1-7.

https://pangea.stanford.edu/ERE/pdf/IGAstandard/SGW/2018/Ghazali.pdf

[11] Moslemizadeh, A., Shadizadeh, S.R. and Moomenie, M. (2015) Experimental Investigation of the Effect of Henna Extract on the Swelling of Sodium Bentonite in Aqueous Solution. Applied Clay Science, 105, 78-88.

https://doi.org/10.1016/j.clay.2014.12.025

[12] Clark, R.K. (1994) Impact of Environmental Regulations on Drilling-Fluid Technology. Journal of Petroleum Technology, 46, 804-809.

https://doi.org/10.2118/27979-PA

[13] United Nations Environment Programme (1985) The Impact of Water-Based Drilling Mud Discharges on the Environment: An Overview.

https://wedocs.unep.org/bitstream/handle/20.500.11822/30343/TIWBDME.pdf?seq uence $=1$ \&isAllowed $=\mathrm{y}$

[14] Prasad, S., Yadav, K.K., Kumar, S., Gupta, N., Cabral-Pinto, M.M.S., Rezania, S., Radwan, N. and Alam, J. (2021) Chromium Contamination and Effect on Environmental Health and Its Remediation: A Sustainable Approaches. Journal of Environmental Management, 285, Article ID: 112174.

https://doi.org/10.1016/j.jenvman.2021.112174

[15] World Health Organization (2000) Air Quality Guidelines for Europe. Second Edition, WHO Regional Office for Europe, Copenhagen.

https://apps.who.int/iris/bitstream/handle/10665/107335/E71922.pdf?sequence $=1$ 
[16] Kelessidis, V.C., Tsamantaki, C., Michalakis, A., Christidis, G.E., Makri, P., Papanicolaou, K. and Foscolos, A. (2007) Greek Lignites as Additives for Controlling Filtration Properties of Water-Bentonite Suspensions at High Temperatures. Fuel, 86, 1112-1121. https://doi.org/10.1016/j.fuel.2006.10.009

[17] Nicora, L.F. and Burrafato, G. (1998) Zirconium Citrate: A New Generation Dispersant for Environmentally Friendly Drilling Fluids. Proceedings IADC/SPE Asia Pacific Drilling Conference, Jakarta, 7-9 September 1998, 357-363. https://doi.org/10.2118/47832-MS

[18] Zhang, L.M. and Yin, D.Y. (1999) Novel Modified Lignosulfonate as Drilling Mud Thinner without Environmental Concerns. Journal of Applied Polymer Science, 74, 1662-1668.

https://doi.org/10.1002/(SICI)1097-4628(19991114)74:7<1662::AID-APP8>3.0.CO; 2-J

[19] King, A.M.Y. and Young, G. (1999) Characteristics and Occurrence of Phenolic Phytochemicals. Journal of the American Dietetic Association, 99, 213-218. https://doi.org/10.1016/S0002-8223(99)00051-6

[20] Bianchi, S., Kroslakova, I., Janzon, R., Mayer, I., Saake, B. and Pichelin, F. (2015) Characterization of Condensed Tannins and Carbohydrates in Hot Water Bark Extracts of European Softwood Species. Phytochemistry, 120, 53-61.

https://doi.org/10.1016/j.phytochem.2015.10.006

[21] Case, P.A., Bizama, C., Segura, C., Wheeler, M.C., Berg, A. and DeSisto, W.J. (2014) Pyrolysis of Pre-Treated Tannins Obtained from Radiata Pine Bark. Journal of Analytical and Applied Pyrolysis, 107, 250-255.

https://doi.org/10.1016/j.jaap.2014.03.009

[22] Duval, V. and Averous, L. (2016) Characterization and Physicochemical Properties of Condensed Tannins from Acacia Catechu. Journal of Agricultural and Food Chemistry, 64, 1751-1760. https://doi.org/10.1021/acs.jafc.5b05671

[23] Garro Galvez, J.M., Riedl, B. and Conner, A.H. (1997) Analytical Studies on Tara Tannins. Holzforschung, 51, 235-243. https://doi.org/10.1515/hfsg.1997.51.3.235

[24] Gaugler, M. and Grigsby, W.J. (2009) Thermal Degradation of Condensed Tannins from Radiata Pine Bark. Journal of Wood Chemistry and Technology, 29, 305-321. https://doi.org/10.1080/02773810903165671

[25] Handayani, P.A., Chafidz, A., Ramadani, N.S. and Kartika, D. (2019) Microwave Assisted Extraction (MAE) Process of Tannin from Mangrove Propagules Waste as Natural Dye for Coloring Batik Tulis. Key Engineering Materials, 805, 128-133. https://doi.org/10.4028/www.scientific.net/KEM.805.128

[26] Kaal, J., Nierop, K.G., Kraal, P. and Preston, C.M. (2012) A First Step towards Identification of Tannin-Derived Black Carbon: Conventional Pyrolysis (Py-GC-MS) and Thermally Assisted Hydrolysis and Methylation (THM-GC-MS) of Charred Condensed Tannins. Organic Geochemistry, 47, 99-108. https://doi.org/10.1016/j.orggeochem.2012.03.009

[27] Luo, C., Grigsby, W., Edmonds, N., Easteal, A. and Al-Hakkak, J. (2010) Synthesis, Characterization, and Thermal Behaviors of Tannin Stearates Prepared from Quebracho and Pine Bark Extracts. Journal of Applied Polymer Science, 117, 352-360. https://doi.org/10.1002/app.31545

[28] Luo, X., Bai, R., Zhen, D., Yang, Z., Huang, D., Mao, H., Li, X., Zou, H., Xiang, Y., Liu, K., Wen, Z. and Fu, C. (2019) Response Surface Optimization of the Enzyme-Based Ultrasound-Assisted Extraction of Acorn Tannins and Their Corrosion Inhibition Properties. Industrial Crops and Products, 129, 405-413. 
https://doi.org/10.1016/j.indcrop.2018.12.029

[29] Wang, C.C., Chen, H.F., Wu, J.Y. and Chen, L.G. (2019) Stability of Principal Hydrolysable Tannins from Trapa Taiwanensis Hulls. Molecules, 24, Article No. 365. https://doi.org/10.3390/molecules24020365

[30] Brahim, M., Gambier, F. and Brosse, N. (2014) Optimization of Polyphenols Extraction from Grape Residues in Water Medium. Industrial Crops and Products, 52, 18-22. https://doi.org/10.1016/j.indcrop.2013.10.030

[31] Aires, A., Carvalho, R. and Saavedra, M.J. (2016) Valorization of Solid Wastes from Chestnut Industry Processing: Extraction and Optimization of Polyphenols, Tannins and Ellagitannins and Its Potential for Adhesives, Cosmetic and Pharmaceutical Industry. Waste Management, 48, 457-464. https://doi.org/10.1016/j.wasman.2015.11.019

[32] Low, J.H., Rahman, V. and Jamaluddin, J. (2015) The Influence of Extraction Parameters on Spent Coffee Grounds as a Renewable Tannin Resource. Journal of Cleaner Production, 101, 222-228. https://doi.org/10.1016/j.jclepro.2015.03.094

[33] Lazar, L., Talmaciu, A.I., Volf, I. and Popa, V.I. (2016) Kinetic Modeling of the Ultrasound-Assisted Extraction of Polyphenols from Picea Abies Bark. Ultrasonics Sonochemistry, 32, 191-197. https://doi.org/10.1016/j.ultsonch.2016.03.009

[34] Capparucci, C., Gironi, F. and Piemonte, V. (2011) Equilibrium and Extraction Kinetics of Tannins from Chestnut Tree Wood in Water Solutions. Asia-Pacific Journal of Chemical Engineering, 6, 606-612. https://doi.org/10.1002/apj.455

[35] Chupin, L., Maunu, S.L., Reynaud, S., Pizzi, A., Charrier, B. and Charrier-EL Bouhtoury, F. (2015) Microwave Assisted Extraction of Maritime Pine (Pinus pinaster) Bark: Impact of Particle Size and Characterization. Industrial Crops and Products, 65, 142-149. https://doi.org/10.1016/j.indcrop.2014.11.052

[36] Xia, Z., Singh, A., Kiratitanavit, W., Mosurkal, R., Kumar, J. and Nagarajan, R. (2015) Unraveling the Mechanism of Thermal and Thermo-Oxidative Degradation of Tannic Acid. Thermochimica Acta, 605, 77-85. https://doi.org/10.1016/j.tca.2015.02.016

[37] Mahmoud, S.B., Saad, H., Charrier, B., Pizzi, A., Rode, K., Ayed, N. and Charrier-El Bouhtoury, F. (2015) Characterization of Sumac (Rhus tripartitum) Root Barks Tannin for a Potential Use in Wood Adhesives Formulation. Wood Science and Technology, 49, 205-221. https://doi.org/10.1007/s00226-014-0686-4

[38] Markom, M., Hasan, M., Daud, W.R.W., Singh, H. and Jahim, J.M. (2007) Extraction of Hydrolysable Tannins from Phyllanthus niruri Linn.: Effects of Solvents and Extraction Methods. Separation and Purification Technology, 52, 487-496. https://doi.org/10.1016/j.seppur.2006.06.003

[39] Fraga-Corral, M., García-Oliveira, P., Pereira, A.G., Lourenço-Lopes, C., Jimenez-Lopez, C., Prieto, M.A. and Simal-Gandara, J. (2020) Technological Application of Tannin-Based Extracts. Molecules, 25, Article No. 614. https://doi.org/10.3390/molecules25030614

[40] Ntenga, R., Pagore, F., Pizzi, A., Mfoumou, E. and Ohandja, L. (2017) Characterization of Tannin-Based Resins from the Barks of Ficus platyphylla and of Vitellaria paradoxa: Composites' Performances and Applications. Materials Sciences and Applications, 8, 899-917. https://doi.org/10.4236/msa.2017.812066

[41] Hagerman, A.E. (1988) Extraction of Tannin from Fresh and Preserved Leaves. Journal of Chemical Ecology, 14, 453-461. https://doi.org/10.1007/BF01013897

[42] Nam, S., Kim, H.J., Condon, B.D., Hinchliffe, D.J., Chang, S., McCarty, J.C. and Madison, C.A. (2016) High Resistance to Thermal Decomposition in Brown Cotton 
Is Linked to Tannins and Sodium Content. Cellulose, 23, 1137-1152. https://doi.org/10.1007/s10570-016-0871-8

[43] Tributsch, H. and Fiechter, S. (2008) The Material Strategy of Fire-Resistant Tree Barks. High Performance Structures and Materials IV, 97, 43-52. https://doi.org/10.2495/HPSM080051

[44] Pinto, O., Romero, R., Carrier, M., Appelt, J. and Segura, C. (2018) Fast Pyrolysis of Tannins from Pine Bark as a Renewable Source of Catechols. Journal of Analytical and Applied Pyrolysis, 136, 69-76. https://doi.org/10.1016/j.jaap.2018.10.022

[45] Sebestyén, Z., Jakab, E., Badea, E., Barta-Rajnai, E., Şendrea, C. and Czégény, Z. (2019) Thermal Degradation Study of Vegetable Tannins and Vegetable Tanned Leathers. Journal of Analytical and Applied Pyrolysis, 138, 178-187. https://doi.org/10.1016/j.jaap.2018.12.022

[46] Pantoja-Castro, M.A. and González-Rodríguez, H. (2011) Study by Infrared Spectroscopy and Thermogravimetric Analysis of Tannins and Tannic Acid. Revista latinoamericana de química, 39, 107-112. http://www.scielo.org.mx/scielo.php?pid=S0370-59432011000200003\&script=sci_ar $\underline{\text { ttext }}$

[47] Hafshejani, K.S., Moslemizadeh, A. and Shahbazi, K. (2016) A Novel Bio-Based Deflocculant for Bentonite Drilling Mud. Applied Clay Science, 127-128, 23-34. https://doi.org/10.1016/j.clay.2016.03.037

[48] Khan, M.A., Al-Salim, H.S. and Arsanjani, L.N. (2020) Development of High Temperature High Pressure (HTHP) Water-Based Drilling Mud Using Synthetic Polymers and Nanoparticles. Journal of Advanced Research in Fluid Mechanics and Thermal Sciences, 47, 99-108.

https://www.akademiabaru.com/submit/index.php/arfmts/article/view/2244

[49] Vryzas, Z., Zaspalis, V., Nalbandian, L., Terzidou, A. and Kelessidis, V.C. (2018) Rheological and HP/HT Fluid Loss Behavior of Nano-Based Drilling Fluids Utilizing Fe3O4 Nanoparticles. Materials Today: Proceedings, 5, 27387-27396. https://doi.org/10.1016/j.matpr.2018.09.056

[50] Annis, M.R. (1967) High-Temperature Flow Properties of Water-Base Drilling Fluids. Journal of Petroleum Technology, 19, 1074-1080. https://doi.org/10.2118/1698-PA

[51] Choo, K.Y. and Bai, K. (2015) Effects of Bentonite Concentration and Solution Ph on the Rheological Properties and Long-Term Stabilities of Bentonite Suspensions. Applied Clay Science, 108, 182-190. https://doi.org/10.1016/j.clay.2015.02.023

[52] Kelessidis, V.C., Tsamantaki, C. and Dalamarinis, P. (2007) Effect of Ph and Electrolyte on the Rheology of Aqueous Wyoming Bentonite Dispersions. Applied Clay Science, 38, 86-96. https://doi.org/10.1016/j.clay.2007.01.011

[53] Neshat, J. and Shadizadeh, S.R. (2016) Evaluation of a Naturally-Derived Deflocculant (Terminalia chebula) in Bentonite Dispersions. Iranian Journal of Oil \& Gas Science and Technology, 5, 21-44.

[54] Tehrani, A., Young, S., Gerrard, D. and Fernandez, J. (2009) Environmentally Friendly Water-Based Fluid For HT/HP Drilling. Proceedings SPE International Symposium on Oilfield Chemistry, The Woodlands, 20-22 April 2009, 1-8. https://doi.org/10.2118/121783-MS

[55] Kania, D., Yunus, R., Omar, R., Rashid, S.A., Jan, B.M. and Arsanjani, N. (2018) Nonionic Polyol Esters as Thinner and Lubricity Enhancer for Synthetic-Based Drilling Fluids. Journal of Molecular Liquids, 266, 846-855.

https://doi.org/10.1016/j.molliq.2018.07.014 
[56] Chesser, B.G. and Enright, D.P. (1980) High-Temperature Stabilization of Drilling Fluids with a Low-Molecular-Weight Copolymer. Journal of Petroleum Technology, 32, 950-956. https://doi.org/10.2118/8224-PA

[57] Narayana, P.Y. (1938) Rotary Drilling Mud. Part I. The Effect of Tannin on the Viscosity. Journal of the Indian Institute of Science, 21, 169-170. http://journal.iisc.ernet.in/index.php/iisc/article/viewFile/1426/1458

[58] Mohamad Ibrahim, M.N., Chuah, S.B. and Cheng, P.Y. (2003) Tin-Tannin-Lignosulfonate Complex: An Improved Lignosulfonate-Based Drilling Fluid Thinner. Jurnal Teknologi, 38, 25-32.

[59] Ghazali, N.A., Naganawa, S. and Masuda, Y. (2018) Development of Modified Rhizophora Spp. Tannin Biopolymer Additive in Drilling Fluid System for High Temperature Well Applications. Proceedings IADC/SPE Asia Pacific Drilling Technology Conference, Bangkok, 27-29 August 2018, 1-8. https://doi.org/10.2118/191080-MS

[60] Mohamad Ibrahim, M.N., Azian, H. and Mohd Yusop, M.R. (2006) The Effects of Lignin Purification on the Performance of Iron Complex Drilling Mud Thinner. Jurnal Teknologi, 44, 83-94. https://doi.org/10.11113/jt.v44.387

[61] Ismail, A.R., Norddin, M.M., Latefi, N.A., Oseh, J.O., Ismail, I., Gbadamosi, A.O. and Agi, A.J. (2020) Evaluation of a Naturally Derived Tannin Extracts Biopolymer Additive in Drilling Muds for High-Temperature Well Applications. Journal of Petroleum Exploration and Production Technology, 10, 623-639. https://doi.org/10.1007/s13202-019-0717-7

[62] Pérez, M.A., Rengifo, R., Pereira, C. and Hernández, V. (2017) Dividivi Tannins: An Ecological Product for Water-Based Drilling Fluids. Environment, Development and Sustainability, 19, 1815-1829. https://doi.org/10.1007/s10668-016-9829-0

[63] Pérez, M.A. and Colina, R.A. (2015) Rherological Behavior of Water-Based Drilling Fluids Contaminated with Gypsum $\left(\mathrm{Caso}_{4}\right)$ Using Unmodified Dividivi Tannins (Caesalpinia coriaria) as Deflocculant Agent. Proceedings SPE Latin American and Caribbean Petroleum Engineering Conference, Quito, 18-20 November 2015, 1-7. https://doi.org/10.2118/177032-MS

[64] Neshat, J., Hosseini, E. and Habibnia, B. (2015) Effect of a Naturally Derived Deflocculant (Black Myrobalan) On Rheological Behavior of Heavy Drilling Fluids. American Journal of Oil and Chemical Technologies, 3, 45-47.

https://www.researchgate.net/profile/Jalal-Neshat/publication/298344346_Effect_of a_Naturally_Derived_Deflocculant_Black_Myrobalan_on_Rheological_Behavior_ of_Heavy_Drilling_Fluids/links/56e81f4308aea51e7f3b19df/Effect-of-a-Naturally-D erived-Deflocculant-Black-Myrobalan-on-Rheological-Behavior-of-Heavy-DrillingFluids.pdf

[65] Muhayyidin, A.H.M., Bakar, N.A., Sauki, A., Ghazali, N.A., Jan, B.M., Ibrahim, W.A. and Naimi, F.M. (2019) Rheological and Filtration Performances of Rhizophora mucronata Tannin Water-Based Drilling Fluid. Materials Today. Proceedings, 17, 768-777. https://doi.org/10.1016/j.matpr.2019.06.361

[66] Duman, O. and Tunç, S. (2008) Electrokinetic and Rheological Properties of Na-Bentonite in Some Electrolyte Solutions. Microporous and Mesoporous Materials, 117, 331-338. https://doi.org/10.1016/j.micromeso.2008.07.007

[67] Larsson, M., Hill, A. and Duffy, J. (2012) Suspension Stability; Why Particle Size, Zeta Potential and Rheology Are Important. Annual Transactions of the Nordic Rheology Society, 20, 209-214.

https://www.researchgate.net/profile/J-Duffy-3/publication/279851764_Suspension 
SStability_Why_Particle_Size_Zeta_Potential_and_Rheology_are_Important/links/ 559bffbd08ae7f3eb4cee831/Suspension-Stability-Why-Particle-Size-Zeta-Potentialand-Rheology-are-Important.pdf

[68] Clements, W.R., Nevins, M.J. and Scearce, F.A. (1985) Electrolyte-Tolerant Polymers for High-Temperature Drilling Fluids. Proceedings SPE 1985 California Regional Meeting, Bakersfield, 27-29 March 1985, 257-264. https://doi.org/10.2118/13614-MS

[69] Lisperguer, J., Saravia, Y. and Vergara, E. (2016) Structure and Thermal Behavior of Tannins from Acacia Dealbata Bark and Their Reactivity toward Formaldehyde. Journal of the Chilean Chemical Society, 61, 3188-3190.

https://doi.org/10.4067/S0717-97072016000400007 


\section{Appendix}

Table 1. Thermogravimetric analysis of vegetable-based tannins.

\begin{tabular}{|c|c|c|c|c|}
\hline Sample & Analysis conditions & \multicolumn{2}{|c|}{ Parameters } & Reference \\
\hline \multirow{8}{*}{ Tannic acid } & \multirow{4}{*}{$\begin{array}{l}\text { Heated from room temperature to } \\
750^{\circ} \mathrm{C} \text { at } 20^{\circ} \mathrm{C} / \mathrm{min} \text { under Nitrogen } \\
\text { atmosphere }\end{array}$} & ${ }^{\mathrm{a}} \mathrm{T}_{\text {peak }}$ & $333^{\circ} \mathrm{C}$ & \multirow{8}{*}{ [36] } \\
\hline & & ${ }^{\mathrm{b}} \mathrm{T}_{10 \%}$ & $261^{\circ} \mathrm{C}$ & \\
\hline & & ${ }^{\mathrm{b}} \mathrm{T}_{50 \%}$ & $354^{\circ} \mathrm{C}$ & \\
\hline & & Char remaining & $27 \%$ & \\
\hline & \multirow{4}{*}{$\begin{array}{l}\text { Heated from room temperature to } \\
750^{\circ} \mathrm{C} \text { at } 20^{\circ} \mathrm{C} / \text { min under Air } \\
\text { atmosphere }\end{array}$} & $\mathrm{T}_{\text {peak }}$ & $325^{\circ} \mathrm{C}$ & \\
\hline & & $\mathrm{T}_{10 \%}$ & $258^{\circ} \mathrm{C}$ & \\
\hline & & $\mathrm{T}_{50 \%}$ & $402^{\circ} \mathrm{C}$ & \\
\hline & & Char remaining & $1.4 \%$ & \\
\hline \multirow{4}{*}{ Catechin } & \multirow{12}{*}{$\begin{array}{l}\text { Heated from room temperature to } \\
800^{\circ} \mathrm{C} \text { at } 5^{\circ} \mathrm{C} / \text { min under Nitrogen } \\
\text { atmosphere }\end{array}$} & $\mathrm{T}_{\text {peak }}$ & $285^{\circ} \mathrm{C}$ & \multirow{12}{*}[44]{} \\
\hline & & $\mathrm{T}_{10 \%}$ & $240^{\circ} \mathrm{C}$ & \\
\hline & & $\mathrm{T}_{50 \%}$ & $590^{\circ} \mathrm{C}$ & \\
\hline & & Char remaining & $49 \%$ & \\
\hline \multirow{4}{*}{ Pinus radiata bark } & & $\mathrm{T}_{\text {peak }}$ & $350^{\circ} \mathrm{C}$ & \\
\hline & & $\mathrm{T}_{10 \%}$ & $250^{\circ} \mathrm{C}$ & \\
\hline & & $\mathrm{T}_{50 \%}$ & $460^{\circ} \mathrm{C}$ & \\
\hline & & Char remaining & $40 \%$ & \\
\hline \multirow{4}{*}{$\begin{array}{c}\text { Water } \\
\text { insoluble tannins }\end{array}$} & & $\mathrm{T}_{\text {peak }}$ & $280^{\circ} \mathrm{C}$ & \\
\hline & & $\mathrm{T}_{10 \%}$ & $270^{\circ} \mathrm{C}$ & \\
\hline & & $\mathrm{T}_{50 \%}$ & $650^{\circ} \mathrm{C}$ & \\
\hline & & Char remaining & $47 \%$ & \\
\hline \multirow{4}{*}{ Chestnut extract } & \multirow{16}{*}{$\begin{array}{l}\text { Heated from room temperature to } \\
900^{\circ} \mathrm{C} \text { at } 20^{\circ} \mathrm{C} / \text { min under Argon } \\
\text { atmosphere }\end{array}$} & $\mathrm{T}_{\text {peak }}$ & $312^{\circ} \mathrm{C}$ & \multirow{16}{*}{ [45] } \\
\hline & & $\mathrm{T}_{10 \%}$ & $260^{\circ} \mathrm{C}$ & \\
\hline & & $\mathrm{T}_{50 \%}$ & $590^{\circ} \mathrm{C}$ & \\
\hline & & Char remaining & $40 \%$ & \\
\hline \multirow{4}{*}{ Valonea extract } & & $\mathrm{T}_{\text {peak }}$ & $302^{\circ} \mathrm{C}$ & \\
\hline & & $\mathrm{T}_{10 \%}$ & $250^{\circ} \mathrm{C}$ & \\
\hline & & $\mathrm{T}_{50 \%}$ & $550^{\circ} \mathrm{C}$ & \\
\hline & & Char remaining & $40 \%$ & \\
\hline \multirow{4}{*}{ Tara extract } & & $\mathrm{T}_{\text {peak }}$ & $305^{\circ} \mathrm{C}$ & \\
\hline & & $\mathrm{T}_{10 \%}$ & $240^{\circ} \mathrm{C}$ & \\
\hline & & $\mathrm{T}_{50 \%}$ & $340^{\circ} \mathrm{C}$ & \\
\hline & & Char remaining & $28 \%$ & \\
\hline \multirow{4}{*}{ Quebracho extract } & & $\mathrm{T}_{\text {peak }}$ & $275^{\circ} \mathrm{C}$ & \\
\hline & & $\mathrm{T}_{10 \%}$ & $270^{\circ} \mathrm{C}$ & \\
\hline & & $\mathrm{T}_{50 \%}$ & $750^{\circ} \mathrm{C}$ & \\
\hline & & Char remaining & $49 \%$ & \\
\hline
\end{tabular}




\section{Continued}

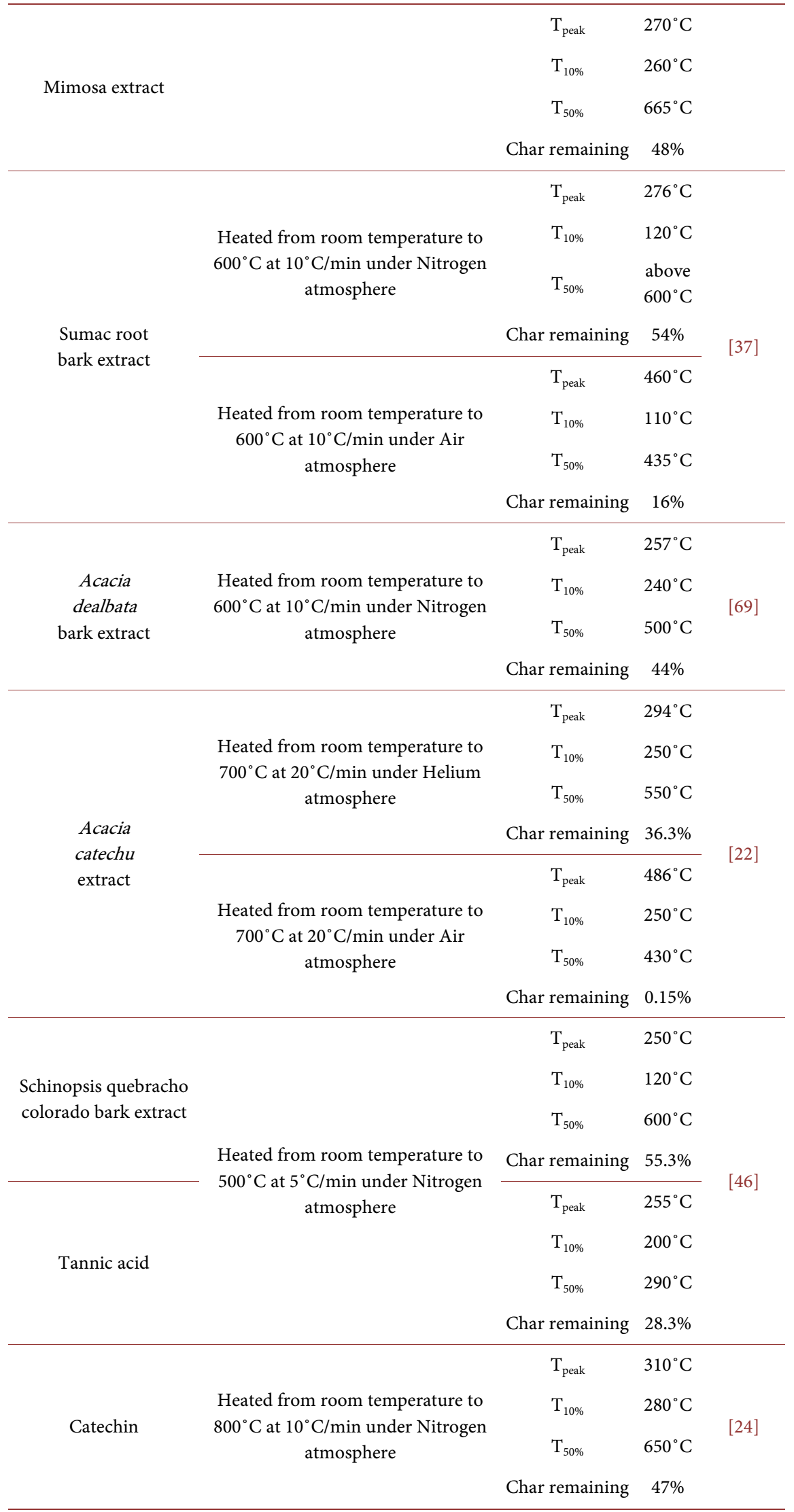




\section{Continued}

\begin{tabular}{|c|c|c|}
\hline \multirow{5}{*}{$\begin{array}{c}\text { Crude HW } \\
\text { (Hot water extract } \\
\text { of pine bark) }\end{array}$} & $\mathrm{T}_{\text {peak }}$ & $280^{\circ} \mathrm{C}$ \\
\hline & $\mathrm{T}_{10 \%}$ & $270^{\circ} \mathrm{C}$ \\
\hline & & \\
\hline & $\mathrm{T}_{50 \%}$ & $520^{\circ} \mathrm{C}$ \\
\hline & Char remaining & $32 \%$ \\
\hline \multirow{4}{*}{$\begin{array}{c}\text { Sulphited HW } \\
\text { (Pine bark } \\
\text { extracted with sodium } \\
\text { sulphite) }\end{array}$} & $\mathrm{T}_{\text {peak }}$ & $275^{\circ} \mathrm{C}$ \\
\hline & $\mathrm{T}_{10 \%}$ & $230^{\circ} \mathrm{C}$ \\
\hline & $\mathrm{T}_{50 \%}$ & $570^{\circ} \mathrm{C}$ \\
\hline & Char remaining & $34 \%$ \\
\hline \multirow{4}{*}{$\begin{array}{c}\text { Tannin acetate } \\
\text { (Acetylated pine bark } \\
\text { tannin) }\end{array}$} & $\mathrm{T}_{\text {peak }}$ & $340^{\circ} \mathrm{C}$ \\
\hline & $\mathrm{T}_{10 \%}$ & $250^{\circ} \mathrm{C}$ \\
\hline & $\mathrm{T}_{50 \%}$ & $400^{\circ} \mathrm{C}$ \\
\hline & Char remaining & $24 \%$ \\
\hline \multirow{4}{*}{$\begin{array}{c}\text { Purified HW } \\
\text { (HW extract purified by } \\
\text { a novel } \\
\text { fractionation } \\
\text { process) }\end{array}$} & $\mathrm{T}_{\text {peak }}$ & $280^{\circ} \mathrm{C}$ \\
\hline & $\mathrm{T}_{10 \%}$ & $300^{\circ} \mathrm{C}$ \\
\hline & $\mathrm{T}_{50 \%}$ & $550^{\circ} \mathrm{C}$ \\
\hline & Char remaining & $38 \%$ \\
\hline \multirow{4}{*}{$\begin{array}{c}\text { Ultafiltered HW } \\
\text { (HW pine bark extract } \\
\text { ultrafiltered) }\end{array}$} & $\mathrm{T}_{\text {peak }}$ & $280^{\circ} \mathrm{C}$ \\
\hline & $\mathrm{T}_{10 \%}$ & $300^{\circ} \mathrm{C}$ \\
\hline & $\mathrm{T}_{50 \%}$ & $730^{\circ} \mathrm{C}$ \\
\hline & Char remaining & $48 \%$ \\
\hline \multirow{4}{*}{$\begin{array}{c}\text { Carbohydrate rich HW } \\
\text { (A carbohydrate rich } \\
\text { HW extract) }\end{array}$} & $\mathrm{T}_{\text {peak }}$ & $280^{\circ} \mathrm{C}$ \\
\hline & $\mathrm{T}_{10 \%}$ & $270^{\circ} \mathrm{C}$ \\
\hline & $\mathrm{T}_{50 \%}$ & $520^{\circ} \mathrm{C}$ \\
\hline & Char remaining & $32 \%$ \\
\hline \multirow{4}{*}{$\begin{array}{l}\text { Quebracho tannin } \\
\text { (Commercial extract } \\
\text { from Quebracho) }\end{array}$} & $\mathrm{T}_{\text {peak }}$ & $240^{\circ} \mathrm{C}$ \\
\hline & $\mathrm{T}_{10 \%}$ & $250^{\circ} \mathrm{C}$ \\
\hline & $\mathrm{T}_{50 \%}$ & $625^{\circ} \mathrm{C}$ \\
\hline & Char remaining & $37 \%$ \\
\hline
\end{tabular}

a. The peak degradation temperature $\left(\mathrm{T}_{\text {peak }}\right)$ is the temperature at which the maximum rate of weight loss of tannin samples occurs. b. The temperature at which $10 \%$ and $50 \%$ weight loss of tannin sample occurs is represented by $\mathrm{T}_{10 \%}$ and $\mathrm{T}_{50 \%}$ respectively.

\section{Nomenclature}

BHSP — Bottom hole Static Pressure

BHST - Bottom hole Static Temperature

CLS-Chrome Lignosulfonate

FCLS-Ferrochrome Lignosulfonate

FTL-Ferro-Tannin-Lignin

FTLS-Ferro-Tannin-Lignosulfonate 
HTHP_High Temperature High Pressure

LS-Lignosulfonate

MDT-Modified Desco Tannin

OSE-Oak Seed Extract

OBDF-Oil-Based Drilling Fluid

RMTE-Rhizophora Mucronata Tannin Extract

RTLS-Rhizophora Tannin-Lignosulfonate

TBD-Tannin-Based Deflocculant

TGA-Thermogravimetric Analysis

TTLS-Tin-Tannin-Lignosulfonate

UDT-Unmodified Dividivi Tannins

WBDF-Water-Based Drilling Fluid 